\title{
Climatization Systems and Sanitary Hot Water in Energetic Certification of Buildings-A Case Study
}

\author{
Claudia Ribeiro Pacheco FFP* and Jose Pacheco de Carvalho AR \\ Department of Physics, Applied Physics and Telecommunications Research Group, Universidade da Beira Interior, Portugal
}

Submission: January 15, 2021; Published: January 20, 2021

*Corresponding author: Claudia Ribeiro Pacheco FFP, Department of Physics, Applied Physics and Telecommunications Research Group, Universidade da Beira Interior, 6201-001 Covilha, Portugal

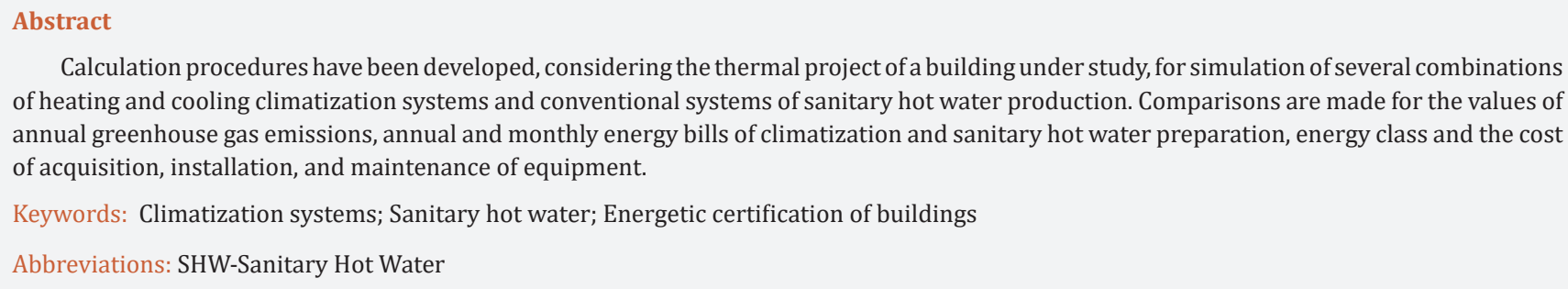

Calculation procedures have been developed, considering the thermal project of a building under study, for simulation of several combinations of heating and cooling climatization systems and conventional systems of sanitary hot water production. Comparisons are made for the values of annual greenhouse gas emissions, annual and monthly energy bills of climatization and sanitary hot water preparation, energy class and the cost of acquisition, installation, and maintenance of equipment.

Keywords: Climatization systems; Sanitary hot water; Energetic certification of buildings

Abbreviations: SHW-Sanitary Hot Water

\section{Opinion}

The transposition of Directive 2002/91/ EC [1], made it possible to compare energetic performance of buildings in different State Members of Europe, based on mutually established parameters [2]. To meet energy requirements, minimum requirements, air quality and energy class, an integrated analysis of both architectural and equipment solutions becomes relevant [3]. In buildings, there are several solutions, which lead to different energy performances. However, it is not necessarily mandatory that a low energy bill corresponds to a good energy rating $[3,4]$.

The building of our case study was a detached single-family home [3]. The systems analyzed included a set of air conditioning (heating and cooling) and SHW production equipment available locally and currently used in single-family housing buildings. Ten solutions were analyzed, S1 to S10. Briefly we have:

a. S1-Standard system, comprising a heating system composed of electrical resistances, a cooling system composed of a refrigerating machine with a performance coefficient of 3 and a SHW production system through an electric water heater with $50 \mathrm{~mm}$ of thermal insulation in buildings without gas supply, or through a natural gas or LPG heater when the supply is foreseen. b. S2-Heat pump / Refrigerating machine for heating / cooling and natural gas boiler for SHW.

c. S3-Heat pump / Refrigerating machine for heating / cooling and electric water heater for SHW.

d. S4-Heat pump / Refrigerating machine for heating / cooling and heat pumps for SHW.

e. S5-Butane gas wall boiler for heating and instant SHW.

f. S6-Wall-mounted natural gas boiler for heating and instant SHW.

g. S7-Wall-mounted natural gas condensing boiler for heating and instant SHW.

h. S8-Diesel floor boiler with accumulation for condensation and SHW by accumulation.

i. S9-Biomass boiler for heating and wall-mounted natural gas boiler for SHW.

j. S10-Biomass boiler for heating and SHW with accumulation. 
To compare the air conditioning and SHW production solutions in the house under study, the following performance indicators were selected for new buildings: Energy rating, where the energy rating scale for buildings or building fractions is made up of 9 classes, in line with the provisions of EN 15217 [5];

$\mathrm{CO}_{2}$ emission rate; Energy bill; Return on investment period.

This work has shown that the impact of climatization and SHW systems on Energy Certification is very significant. A building that combines exceptional insulation conditions may have very different energy classes, depending on the adopted climatization solution, varying from $\mathrm{B}$ - to $\mathrm{A}+$. In the case of an "existing" building, with poor thermal insulation conditions, in breach of the minimum thermal quality requirements, it may have a high energy class, only disguised by the appropriate choice of equipment. It is possible to reconcile a low annual $\mathrm{CO}_{2}$ emission with a low energy bill. However, another important aspect to consider is the cost of installing the equipment. It is possible to reduce the $\mathrm{CO}_{2}$ emission rate and, consequently, obtain a good energy class, which does not necessarily imply a low energy bill or a low installation cost. The solutions that presented the lowest energy bill were: S2) Heat pumps/refrigeration machine for climatization and natural gas boiler for sanitary hot water, S3) Heat pumps/refrigeration machine for climatization and electric water heater for sanitary hot water, S4) Heat pumps for climatization and sanitary hot water. Solution S3 is penalized in terms of $\mathrm{CO}_{2}$ emissions, so solutions $\mathrm{S} 2$ and $\mathrm{S} 4$ are more favorable. However, solution S4 has a higher installation cost, compared to solution S2 and a longer simple payback period.

\section{Conclusion}

Some conclusions can be highlighted: The performance indicators analyzed are relevant parameters in helping to decide on the climatization and support systems for SHW to be implemented. The most appropriate balance between the various indicators must be technically justified in order to enable the decision maker to choose the most convenient solution, its advantages and disadvantages. The weight of the climatization and SHW production systems, both in the energy bill and in the energy classification, is very significant, and it is recommended that the decision on these systems be evaluated by the different specialties involved. A good energy classification, with reduced $\mathrm{CO}_{2}$ emission rates, does not necessarily correspond to a lower energy bill.

\section{Acknowledgement}

Supports from University of Beira Interior and FCT (Fundação para a Ciência e a Tecnologia, Portugal)/PEstOE/FIS/UI0524/2014(ProjectoEstratégico-UI524-2014)are acknowledged.

\section{References}

1. (2003) Directive No. 2002/91 / EC of 16 December-Energy Performance of Buildings, Official Journal of the European Communities EN. p: 1-7.

2. Isolani P, Comini, R, Clement F, Puente F, Orlandi A et al. (2008) Energy efficiency in residential buildings. Deco editions, Lisbon, Portugal.

3. (2010) Pacheco, Cláudia FFPR. Impact of Climatization and DHW Systems on Certification Energetics of Buildings under the RCCTE: Case Study, M. Sc thesis, University of Beira, Interior, Covilha, Portugal.

4. (2006) Decree-Law no. 80/2006 of 4 April, which approves the Regulation on the Characteristics of Thermal Behavior of Buildings (RCCTE), replaces DL 40/1990, Diário da República № 67, 1 A-series. p: $1-46$.

5. (2007) EN 15217- Energy performance of buildings-Methods for expressing energy performance and for energy certification of buildings, CEN.

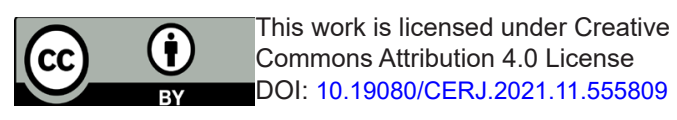

\begin{tabular}{l} 
Your next submission with Juniper Publishers \\
will reach you the below assets \\
- Quality Editorial service \\
- Swift Peer Review \\
- Reprints availability \\
- E-prints Service \\
- Manuscript Podcast for convenient understanding \\
- Global attainment for your research \\
- Manuscript accessibility in different formats \\
( Pdf, E-pub, Full Text, Audio) \\
- Unceasing customer service \\
Track the below URL for one-step submission \\
https://juniperpublishers.com/online-submission.php \\
\hline
\end{tabular}

